\title{
Retraction Note To: Expression of SOCS2 mRNA and protein in the ischemic core and penumbra after transient focal cerebral ischemia in rats
}

\author{
Yoo-Jin Shin ${ }^{1}$ Tae-Ryong Riew ${ }^{1} \cdot$ Joo-Hee Park $^{1} \cdot$ Ha-Jin Pak ${ }^{1} \cdot$ Mun-Yong Lee ${ }^{1}$
}

Published online: 30 April 2016

(C) Springer-Verlag Berlin Heidelberg 2016

\section{Retraction Note To: Cell Tissue Res}

DOI 10.1007/s00441-015-2319-0

This article has been retracted at the request of the authors, because they found that beta-actin, as the loading control, did not match with SOCS2, as shown in Fig. 7, depicting western blot for SOCS2 protein. The authors therefore request that the paper be retracted, although this result was unintentional and the conclusions in this paper hold valid.

The online version of the original article can be found at http://dx.doi.org/ 10.1007/s00441-015-2319-0.

Yoo-Jin Shin

dbwls612@catholic.ac.kr

$\triangle$ Mun-Yong Lee

munylee@catholic.ac.kr

1 Department of Anatomy, Catholic Neuroscience Institute, College of Medicine, The Catholic University of Korea, Seoul 137-701, South Korea 